\title{
Student Worksheet Development on the Math Division Material Based on the PMRI Approach for Fifth-Grade Elementary School Students
}

\section{Arief Kuswidyanarko $^{1 *}{ }^{*}$ Rohana $^{2}$, Miftahul Jannah ${ }^{3}$}

1,2,3 Pendidikan Guru Sekolah Dasar, Universitas PGRI Palembang, Palembang, Indonesia

\section{A R T I C LE I N F O}

\section{Article history:}

Received September 02, 2021

Revised September 09, 2021

Accepted October 27, 2021

Available online November 25, 2021

\section{Kata Kunci:}

LKPD, Pendekatan PMRI,

Pembagian

Keywords:

Student Worksheet, PMRI

Approach, Division

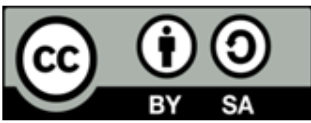

This is an open access article under the CC BY-SA license.

Copyright $(2021$ by Author. Published by Universitas Pendidikan Ganesha.

\begin{abstract}
A B S T R A K
Siswa mengalami kesulitan dalam belajar matematika sehingga siswa meyakini bahwa matematika sangat sulit, terutama bagi siswa sekolah dasar. Hal ini berdampak pada hasil belajar siswa yang menurun. Penelitian ini bertujuan untuk menghasilkan LKPD pada materi pembagian berbasis pendekatan PMRI yang valid dan praktis untuk pembelajaran. Penelitian pengembangan yang digunakan adalah research and development (R\&D) dengan menggunakan model $4 D$ yang dikembangkan oleh Thiagarajan terdiri dari empat tahapan yaitu: tahap define,tahap design,tahap development dan tahap dissemination. Data yang diperoleh dikumpulkan melalui wawancara, angket dan observasi. Instrument yang digunakan untuk mengumpulkan data yaitu kuesioner. Teknik yang digunakan untuk menganalisis data yaitu analisis deskriptif kualitatif dan kuantitatif. Hasil penilaian diperoleh dari uji validasi oleh tim ahli dengan rata-rata persentase penilaian sebesar $87,5 \%$ ketegori sangat valid. Hasil penilaian diperoleh dari respon peserta didik pada uji coba terbatas memperoleh rata-rata persentase sebesar $84,58 \%$ kategori sangat praktis dan respon peserta didik pada uji coba lapangan dengan persentase penilaian sebesar $82,40 \%$ kategori sangat praktis. Adapun hasil penilaian respon pendidik sebesar $88,75 \%$ kategori sangat praktis. Berdasarkan data tersebut LKPD pada materi pembagian berbasis pendekatan PMRI telah memenuhi kriteria kevalidan dan juga kepraktisan sehingga LKPD yang dikembangkan layak untuk digunakan dalam proses pembelajaran.
\end{abstract}

\section{A B S T R A C T}

Students have difficulty learning mathematics, so it can be concluded that mathematics is complicated, especially for elementary school students. It has an impact on student learning outcomes that decline. This study aims to produce LKPD on material distribution based on a valid and practical PMRI approach for learning. The development research used is research and development (R\&D) using a 4D model developed by Thiagarajan consisting of four stages: define stage, design stage, development stage, and dissemination stage. Data was collected through interviews, questionnaires, and observations. The instrument used to collect data is a questionnaire. The technique used to analyze the data is descriptive qualitative and quantitative analysis. The results obtained from the validation test by experts with an average rating of $87.5 \%$ are excellent categories. The student responses in the limited trial obtained an average percentage of $84.58 \%$ in the efficient category, and the student responses in the field trial with $82.40 \%$ in the efficient category. The results of the assessment of the educator's response were $88.75 \%$ in the efficient category. Based on these data, the LKPD in the distribution material based on the PMRI approach has met the criteria for validity and practicality so that the LKPD developed is feasible to be used in the learning process.

\section{INTRODUCTION}

Education is a deliberate effort to be helpful to someone. In education, the learning process is crucial as it is an adult's effort to guide children to reach the level of maturity intended to improve children's behavior for the better and gain knowledge, skills, and attitudes to help them develop their personality (Bettencourt et al., 2011; Hashim, 2018; Maulana, 2021). Learning is a transformational process and the 
maturation process undertaken by an educator and student includes activities to fill and develop cognitive abilities with as many facts as possible (Ro'fah et al., 2020; Solehana et al., 2019; Sugiyanto et al., 2019). Students change their knowledge on their own, and a teacher only serve as facilitator, mediator, and role model in the learning process (Kraft \& Papay, 2014; Márquez-García et al., 2020; Ronfeldt et al., 2013). Meanwhile, learning is an activity in which a person attempts to acquire knowledge, skills, and positive values through the use of various learning sources, and learning is a process of communication and interaction as a form of educational effort by conditioning students' learning processes (Fun \& Maskat, 2010; Kin et al., 2018; Toropova et al., 2021).

Moreover, emphasizes the importance of learning activities as the foundation of curriculum implementation (Friedman \& Friedman, 2013; Taylor et al., 2017). Learning activities have a significant impact on academic quality. If the learning activities are suitable, the educational quality will be adequate. In learning, it must be adjusted to students' level of cognitive development (Mpungose, 2021; Wardoyo \& Article, 2016). Children in primary school are those aged 7 to 12 years old. The developmental level of elementary school children is at concrete operations; children will understand more efficiently by using tangible objects (Bujuri, 2018; Partovi \& Razavi, 2019; Pratama et al., 2020). At that age, the developmental level still sees everything in its entirety and can understand the relationship among concepts in simple terms (Antari, 2015; Nurlaily et al., 2019). So that the learning process is easy to do, it is necessary to use teaching materials that can increase understanding of a concept to facilitate achieving the goals (Samri et al., 2020; Yuniarti \& Radia, 2020).

Learning resources are information presented and stored in various forms of media that can assist students in learning as an embodiment of the curriculum (Sugiyanto et al., 2019; Syafrijal \& Desyandri, 2019). Educators must develop teaching materials that can facilitate understanding of concepts and solve problems for the learning process to be successful and for students to understand the concepts they are learning (Bajrami \& Ismaili, 2016; Rosala \& Budiman, 2020). The presence of innovation in the use of worksheets in class and the demands of the applicable curriculum can increase students' critical thinking skills when solving mathematical problems. Students expect active, creative, effective, and enjoyable mathematics learning (Agitsna et al., 2019; Yustina \& Kapsin, 2017). One of the teaching materials that can be developed is a student worksheet. The student worksheet contains sheets to train the development of cognitive aspects and all other elements. Student worksheet is a worksheet that contains information or instructions for students to complete a learning activity in the form of practice or application of results to achieve a certain goal (Astari, 2017; Suryawati et al., 2020). Student worksheets significantly influence learning; student worksheets can encourage the thinking process to facilitate students in solving a problem. Thus, learning resources can be used to facilitate educators in the teaching and learning process (Ayva, 2012; Mutlu, 2020).

However, it is still common to encounter students who have difficulty learning mathematics, causing them to complain and believe that mathematics is extremely difficult, particularly for elementary school students (Öztürk et al., 2020; Shafie et al., 2010; Sulastri \& Kusmanto, 2016). As a result, students do not like math lessons (Hong et al., 2015; Yuniarti \& Radia, 2020). They sometimes have difficulty in solving mathematical problems. It is due to various factors, including a lack of mathematical understanding, a lack of variety in teaching materials, and students' lack of interest in mathematics (Lin et al., 2020; Rahma \& Pujiastuti, 2021). The division is a mathematical concept that is widely used in everyday life. Furthermore, it serves as the foundation for furthering one's knowledge of mathematics (Nenotaek et al., 2019; Tanudjaya \& Doorman, 2020). However, as is the case at the 3rd Belida Darat Public Elementary School, students struggle to cope with the division material. According to information obtained from interviews conducted by the researcher with homeroom teachers for fifth-grade elementary school, students frequently have difficulty understanding the concept of division when learning mathematics. When a student understands a division subject, he can solve the problem. It shows that students continue to struggle with mathematical concepts. These difficulties arise as a result of students' inability to grasp the idea. In addition, students make mistakes when solving problems.

To overcome these challenges, it is necessary to carry out learning activities that assist students in locating and comprehending mathematical concepts and problems. The understanding mathematical concept is also one of the goals of educators, as educators serve as guides to achieve it (Kowiyah et al., 2019; Nugroho et al., 2018). The elementary school level, considered the first foundation, must be strengthened by instilling correct mathematical concepts and skills in students (Russo et al., 2020, 2021). Mathematics education in elementary schools is expected to provide effective and efficient learning by the curriculum and students' mindsets to solve math problems in everyday life quickly. As a result, it employs a mathematics teaching method accustomed to students' minds or relatable to everyday life (G. J. Hwang et al., 2020; Yulianty, 2019). There are many ways to make learning mathematics comfortable and fun, including using various approaches. 
One approach to learning mathematics that can develop creative thinking skills and instill concepts is the Pendidikan Matematika Realistik Indonesia approach (PMRI). To overcome students' difficulties understanding the concept of division, teachers must employ various methods of delivering material and conducting other learning activities, one of which is the PMRI approach (Hanifah et al., 2019; Hasbi et al., 2011). The success of the PMRI approach has been demonstrated in several studies that students who are taught using PMRI will outperform students who are taught conventionally (Budi, 2013; Fauziah et al., 2020). PMRI is the adaptation result of RME (Realistic Mathematics Education) which has been harmonized with the life of the Indonesian people, so the PMRI principle is the same as the RME principle. PMRI is a mathematical approach that uses a real-world context; the problems presented come from real-life situations with students, allowing them to imagine the experiences they will face (Herutomo et al., 2020; N. R. Sari et al., 2019; Sulastri et al., 2017).

This is in line with opinion, that the real world is used as a starting point for the development of mathematical ideas and concepts in PMRI. The PMRI approach presents problems in contexts that are relevant to students' daily lives. It will undoubtedly help students understand mathematical concepts, particularly in the division material. the real world is a concrete world conveyed to students through the use of mathematics. Realistic Mathematics Learning is a method of teaching mathematics that uses realworld contexts as the first step in developing students' knowledge. As a result, students should have access to teaching materials that can help them better understand mathematical concepts (Istiandaru et al., 2015; Novita \& Putra, 2017). This study aims to produce LKPD (Student Worksheet) on material distribution based on the PMRI approach that is valid and practical for learning. It is hoped that LKPD (Student Worksheet) can facilitate students ' learning.

\section{METHOD}

This study is a research and development research that employs Thiagarajan's development model, commonly referred to as $4 \mathrm{D}$. The $4 \mathrm{D}$ model has four research steps; define, design, development, and dissemination. Development research improved existing products or produced new products (Herawati et al., 2018). Based on the PMRI approach, this study generated a product in the form of a student worksheet. This study used the steps of a 4D development model, including: (1) Define which included curriculum analysis, student analysis, material analysis, and learning objective analysis; (2) Design contained activities for compiling a map of needs, determining the structure contained in the student worksheet, and designing research instruments; (3) Development contained activities to test products and revised products that had been tested: (4) Dissemination included activities for disseminating products that had been deemed valid and practical. This development step was chosen because it demonstrated clear steps to producing a product. The stages in the design of this 4D model are simple, easy to learn, and easy to practice in development research.

This research was conducted at the 3rd Belida Darat Public Elementary School which is located in Ibul Village. The data that had been obtained from the research were collected through interviews, expert questionnaires, student and teacher response questionnaires, and observation. Interviews were conducted with the homeroom teacher of fifth-grade students at the 3rd Belida Darat Public Elementary School to determine the potential and problems that existed in the school environment and to gather information before conducting research. Questionnaire of experts to determine the validity of the student worksheet for the learning process, including media expert, material expert, and linguist. Closed questionnaires were used to collect students' responses when using student worksheets based on the PMRI approach. Data collection methods included compiling instruments based on grids, testing the validity of student worksheets, conducting research, and analyzing data obtained from the research. The data from the validity test results by expert judges as product validation were analyzed using a rating scale. The initial analysis of the score data obtained from closed questionnaire results for the expert judges was summed and averaged for each expert's questionnaire. The percentage figures obtained are then interpreted in Table 1. below:

Table 1. Interpretation Scale with Rating Scale

\begin{tabular}{ccc}
\hline No & Persentase (\%) & Kategori \\
\hline 1 & $00,00 \%-20,00 \%$ & Invalid \\
2 & $21,00 \%-40,00 \%$ & Not valid enough \\
3 & $41,00 \%-60,00 \%$ & Quite valid \\
4 & $61,00 \%-80,00 \%$ & Valid \\
5 & $81,00 \%-100,00 \%$ & Very valid \\
\hline
\end{tabular}


Based on the interpretation scale above, the student worksheet can be declared valid for testing if it has a minimum percentage score range of 61 percent or a maximum percentage score range of 100 percent. The practicality of student worksheets is obtained from the teacher and students' responses during product trials.

\section{RESULT AND DISCUSSION}

\section{Result}

The define stage is the first stage carried out by the researcher, and it includes activities such as curriculum analysis. The researcher analyzed students by conducting interviews with the homeroom teacher of fifth-grade students at the 3rd Belida Darat Public Elementary School and creating student worksheets based on curriculum 13. According to the findings of interviews with the fifth-grade homeroom teacher at an elementary school, the learning outcomes of fifth-grade students in mathematics are still very low, particularly the ability to understand the concept of division. It was due to a lack of teaching materials, such as student worksheets explaining mathematical concepts, resulting in low student learning outcomes. Material analysis based on Core Competencies and Basic Competencies in the division material for fifthgrade students, the material in the student worksheets developed consists of three material sub-sections, namely Indonesian Realistic Mathematics Education (PMRI), division of natural numbers with common fractions, and division of common fractions with common fractions. Based on the analysis of learning objectives premised on Basic Competencies in the division material, the learning objectives must be achieved are two. They are; students can understand the division of fractions in the form of natural numbers and common fractions, and students can also solve the problem of dividing fractions in the form of natural numbers and common fractions. The results of the definition stage were used to create student worksheets.

The design stage consisted of compiling a map of student worksheet needs, determining the structure of student worksheets, and designing research instruments. The student worksheet needs map was created by considering the PMRI approach steps, core competencies, basic competencies, and indicators of competency achievement and learning objectives. The map needs of student worksheets were organized to help researchers sort tasks or activities of students to be presented in student worksheets. Student worksheet structure can aid students and teachers in recognizing the elements contained in student worksheets. In general, student worksheets have covers, instructions for use, a table of contents, concept maps, PMRI approach steps, material sub-chapters, activities, and cases or practice questions. The research instrument was used to assess the validity and usability of student worksheets. The validation instrument was a student worksheet validation sheet, and the practical instrument was a student response questionnaire and the teacher's response to the developed student worksheet.

The Development phase is an activity that involves testing the product's validity, revising the product, and testing the product that is being developed. At the development stage, the product will be validated by a team of experts, followed by improvements and conducting limited trials and field trials. After developing student worksheets based on the PMRI approach, the next step was to validate the student worksheets by expert judges consisting of two lecturers, such as linguists, media experts, and one teacher as a material expert. Based on the evaluation results of the three validators that had been processed, the average percentage of media expert lecturers was $80.9 \%$ in the valid category, $88.1 \%$ in the very valid category, and $93.6 \%$ in the very valid category. The average percentage of assessment of all validators was $87.5 \%$, with a very valid category. According to the validator's judgment, the developed student worksheets were in a good category. However, there were still things that needed to be corrected or revised following the validator's directions to be ready for testing at school. The revision of the student worksheet was created in response to the validator's comments, namely:

The next step is to test the student worksheet for fifth-grade students at the 3rd Belida Darat Public Elementary School after the validator declared it valid and revised. The student worksheet was tested in both limited trial and field trials. The limited trial, which included three students and a student response questionnaire, yielded an average of $84.58 \%$ with a very practical category, indicating that the student worksheets had been completed and could be tested in the field. The field trial involved 12 students and yielded an average percentage of $82.40 \%$ in a very practical category. Although the field trial results had decreased in scores than the limited trial result, they are still in the very practical category. The teacher response questionnaire yielded an 88.75 average percentage in a very practical category. Products that have been deemed valid and practical are distributed in a limited manner during the Dessimantion stage. The researcher distributed the final product in student worksheets based on the PMRI approach to the homeroom teacher for fifth-grade students at the 3rd Belida Darat Public Elementary School in the form of 10 student worksheets. Other access can be obtained online by visiting the researcher's Academia.edu 
account on the mebsite below: http://www.academia.edu/56933451/LKPD_PMRI?source=swp_share.

Table 2. Revision Based on Expert Advice

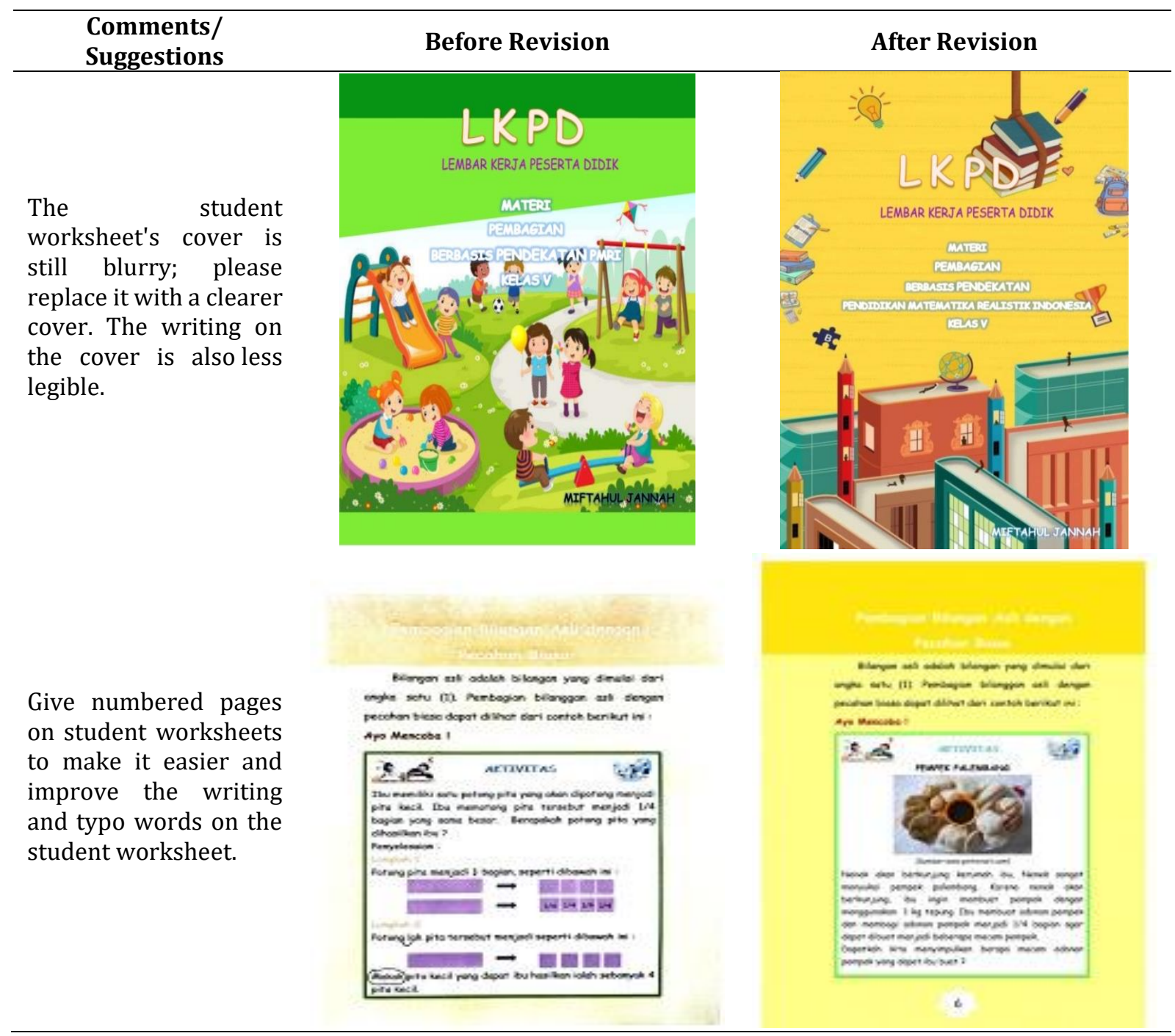

\section{Discussion}

In the whole process of education in schools, learning is an essential activity. Learning is teaching students to use educational principles, and learning theory is the primary determinant of the success of education (Leszczyński et al., 2018; Rodríguez-Izquierdo, 2021). In the whole educational process in schools, learning is an essential activity (Bergdahl et al., 2020; Shafie et al., 2010). Learning is teaching students to use educational principles, and learning theory is the primary determinant of the success of education (Chou, 2013; Demitra \& Sarjoko, 2018). At the initial stage, mathematics is formed from student experience based on existing reality, mathematics as a human activity then that experience is processed by reasoning, processed analytically and synthetically with knowledge arriving at conclusions in the form of mathematical concepts (Kowiyah \& Mulyawati, 2018; Riyanto \& Gunarhadi, 2017). Mathematics is one of the sciences that has enormous benefits in daily human life, and mathematics is also a lesson given to all students starting from elementary school (Davidi et al., 2021; G.-J. Hwang et al., 2021).

Using a realistic approach makes mathematics more engaging, relevant, and meaningful (Sopia \& Wutsqa, 2015; Yulianty, 2019). In addition, this approach uses real-life or everyday contexts as a starting point for learning mathematics (Hidayat et al., 2020; Wahyuni, 2019). Learning using a realistic approach facilitates solving mathematical problems with or without using standard solutions (algorithms) and emphasizes learning mathematics on "learning by doing" (Faidah et al., 2019; Jeheman et al., 2019). One of the teaching materials that can improve students' abilities is LKPD (worksheet). These teaching materials are tools and media that provide opportunities for students to gain experience dealing with facts in life (Indrianingrum et al., 2018; Suryawati et al., 2020; Yustina \& Kapsin, 2017). Through this experience, 
students will practice assessing and developing ideas, solving problems, acquiring skills, and fostering and developing creativity. Student Worksheets (LKPD) are sheets containing tasks that students must do (Marshel \& Ratnawulan, 2020; Mutlu, 2020). Students will get material, summaries, and assignments related to the material (Mutlu, 2020; Zulimah et al., 2018). LKPD makes students able to study the teaching materials independently. The findings of previous studies also stated that LKPD could improve students' understanding of learning (Marshel \& Ratnawulan, 2020; Pentury et al., 2019). Other research findings also state that LKPD can increase students' independence in learning (Marshel \& Ratnawulan, 2020; I. P. Sari \& Purnama, 2014; Yustina \& Kapsin, 2017).

\section{CONCLUSION}

Based on the results of this study, it can be obtained that the level of product validity in the form of LKS of diversion material based on the PMRI approach is feasible to use. The practicality of LKS is evidenced by the response of educators, student responses, and perfect field trials.

\section{REFERENCES}

Agitsna, L. D., Wahyuni, R., Friansah, D., \& Friansah, D. (2019). Pengembangan Lembar Kerja Siswa Berbasis Problem Based Learning Pada Materi Bangun Ruang Sisi Datar Kelas Viii Smp Negeri 11 Lubuklinggau. AKSIOMA: Jurnal Program Studi Pendidikan Matematika, 8(3), 429-437. https: //doi.org/10.24127/ajpm.v8i3.2360.

Antari, L. (2015). Penggunaan Bahan Ajar Tematik Pembagian Untuk Meningkatkan Hasil Belajar Di Kelas Iia Mi Ahliyah Ii Palembang. AKSIOMA Journal of Mathematics Education, 4(2), 22-29. https://doi.org/10.24127/ajpm.v4i2.307.

Astari, T. (2017). Pengembangan Lembar Kerja Siswa (LKS) Berbasis Pendekatan Realistik untuk Meningkatkan Hasil Belajar Siswa SD Kelas IV. Jurnal Pelangi, 9(2), 150-160. https: //doi.org/10.22202/jp.2017.v9i2.2050.

Ayva, O. (2012). Developing Students' Ability to Read, Understand and Analyze Scientific Data Through the Use of Worksheets that Focus on Studying Historical Documents. Procedia - Social and Behavioral Sciences, 46. https://doi.org/10.1016/j.sbspro.2012.06.395.

Bajrami, L., \& Ismaili, M. (2016). The Role of Video Materials in EFL Classrooms. Procedia - Social and Behavioral Sciences, 232(April), 502-506. https://doi.org/10.1016/j.sbspro.2016.10.068.

Bergdahl, N., Nouri, J., \& Fors, U. (2020). Disengagement, engagement and digital skills in technologyenhanced learning. Education and Information Technologies, 25(2), 957-983. https: //doi.org/10.1007/s10639-019-09998-w.

Bettencourt, C., Velho, J. L., \& Almeida, P. A. (2011). Biology teachers' perceptions about Science-TechnologySociety (STS) education. Procedia - Social and Behavioral Sciences, 15. https://doi.org/10.1016/j.sbspro.2011.04.262.

Budi, R. R. S. (2013). Penerapan Pendidikan Matematika Realistik Indonesia Melalui Penggunaan Alat Peraga Praktik Miniatur Tandon Air Terhadap Hasil Belajar Siswa Di Kelas X Sma Negeri 3 Kota Manna. Jurnal Pendidikan Matematika, 2(1). https://doi.org/10.22342/jpm.2.1.299.

Bujuri, D. A. (2018). Analisis Perkembangan Kognitif Anak Usia Dasar dan Implikasinya dalam Kegiatan Belajar Mengajar. LITERASI (Jurnal Ilmu Pendidikan), 9(1), 37. https: //doi.org/10.21927/literasi.2018.9(1).37-50.

Chou, P.-N. (2013). Students Perceptions Of Success In The Online Graduate-Level Classes: A Self-Directed Learning Perspective. Contemporary Issues in Education Research (CIER), 6(1), 115. https://doi.org/10.19030/cier.v6i1.7610.

Davidi, E. I. N., Sennen, E., \& Supardi, K. (2021). Integrasi Pendekatan STEM (Science, Technology, Enggeenering and Mathematic) Untuk Peningkatan Keterampilan Berpikir Kritis Siswa Sekolah Dasar. Scholaria: Jurnal Pendidikan Dan Kebudayaan, 11(1), 11-22. https: //doi.org/10.24246/j.js.2021.v11.i1.p11-22.

Demitra, \& Sarjoko. (2018). Effects of Handep Cooperative Learning Based on Indigenous Knowledge on Mathematical Problem Solving Skill. International Journal of Instruction, 11(2), 103-114. https://doi.org/10.12973/iji.2018.1128a.

Faidah, N., Masykur, R., Andriani, S., \& Lina Herlina. (2019). Realistic Mathematics Education (Rme) Sebagai Sebuah Pendekatan Pada Pengembangan Modul Matematika Berbasis Teori Multiple Intelligences Realistic Mathematics Education ( Rme ) As an Approach To Development of Mathematical Module Based on Multiple Intel. Indonesia Journal of Science and Mathematics Education, 02(3), 328-332. https://doi.org/10.24042/ijsme.v2i3.4396. 
Fauziah, A., Putri, R. I. I., Zulkardi, Z., \& Somakim, S. (2020). Developing PMRI Learning Environment Through Lesson Study For Pre-Service Primary School Teacher. Journal On Mathematics Education, 11(2). https://doi.org/10.22342/jme.11.2.10914.193-208.

Friedman, L. W., \& Friedman, H. H. (2013). Using social media technologies to enhance online learning. Journal of Educators Online, 10(1). https://doi.org/10.9743/JE0.2013.1.5.

Fun, C. S., \& Maskat, N. (2010). Teacher-Centered Mind Mapping vs Student-Centered Mind Mapping in the Teaching of Accounting at Pre-U Level - An Action Research. International Conference on Learner Diversity, 240. https://doi.org/10.1016/j.sbspro.2010.10.034.

Hanifah, R., Noornia, A., \& Sampoerno, P. D. (2019). Pengembangan Pembelajaran Dalam Membangun Pemahaman Relasional Siswa Melalui Pendekatan Pmri Materi Relasi Fungsi. Prima: Jurnal Pendidikan Matematika, 3(2), 103. https://doi.org/10.31000/prima.v3i2.950.

Hasbi, M., Lukito, A., \& Sulaiman, R. (2011). Pengembangan Pembelajaran Matematika Siswa SMP: Koneksi Matematis Pada Realistik Mathematics Education. Infinity Jurnal Matematika Dan Aplikasinya, 1(2).

Hashim, H. (2018). Application of Technology in the Digital Era Education. International Journal of Research in Counseling and Education, 1(2), 1. https://doi.org/10.24036/002za0002.

Herawati, A., Wahyudi, W., \& Indarini, E. (2018). Pengembangan Media Pembelajaran Bangun Ruang Berbasis Discovery Learning dengan Construct 2 dalam Meningkatkan Kemampuan Pemecahan Masalah Matematika. Jurnal Ilmiah Sekolah Dasar, 2(4), 396. https: //doi.org/10.23887/jisd.v2i4.16157.

Herutomo, R. A., Hajeniati, N., \& Mustari, F. (2020). Model Problem-Based Learning Berpendekatan Matematika Realistik untuk Mendukung Literasi Matematis Siswa. Jurnal Pendidikan Matematika, 11(1). https://doi.org/10.36709/jpm.v11i1.9840.

Hidayat, E. I. F., Vivi Yandhari, I. A., \& Alamsyah, T. P. (2020). Efektivitas Pendekatan Realistic Mathematics Education (RME) Untuk Meningkatkan Kemampuan Pemahaman Konsep Matematika Siswa Kelas V. Jurnal Ilmiah Sekolah Dasar, 4(1), 106. https://doi.org/10.23887/jisd.v4i1.21103.

Hong, E., Mason, E., Peng, Y., \& Lee, N. (2015). Effects of homework motivation and worry anxiety on homework achievement in mathematics and English. Educational Research and Evaluation, 21(78), 491-514. https://doi.org/10.1080/13803611.2015.1131721.

Hwang, G.-J., Wang, S.-Y., \& Lai, C.-L. (2021). Effects of a social regulation-based online learning framework on students' learning achievements and behaviors in mathematics. Computers \& Education, 160. https://doi.org/10.1016/j.compedu.2020.104031.

Hwang, G. J., Wang, S. Y., \& Lai, C. L. (2020). Effects of a Social Regulation-Based Online Learning Framework on Students' Learning Achievements and Behaviors in Mathematics. Computers and Education, 160, 104031. https://doi.org/10.1016/j.compedu.2020.104031.

Indrianingrum, R., Mahardika, Ik., Wahyuni, D., a, S., a, I., \& Hariyadi, S. (2018). Effectiveness of Stem-Based Science Student Worksheet in Improving Multiple Representation Ability of Junior High School Students. International Journal of Advanced Research, 6(4), 1366-1369. https: //doi.org/10.21474/ijar01/6995.

Istiandaru, A., Istihapsari, V., Wardono, W., \& Mulyono, M. (2015). Problem Based Learning (PBL) Dengan Pendekatan Realistik-Saintifik dan Asesmen Pisa Untuk Meningkatkan Kemampuan Literasi Matematika. Edumatica: Jurnal Pendidikan Matematika, 5(1). https://doi.org/10.22437/edumatica.v5i01.2670.

Jeheman, A. A., Gunur, B., \& Jelatu, S. (2019). Pengaruh Pendekatan Matematika Realistik terhadap Pemahaman Konsep Matematika Siswa. Mosharafa: Jurnal Pendidikan Matematika, 8(2), 191-202. https://doi.org/10.31980/mosharafa.v8i2.454.

Kin, T. M., Abdull Kareem, O., Nordin, M. S., \& Wai Bing, K. (2018). Principal change leadership competencies and teacher attitudes toward change: the mediating effects of teacher change beliefs. International $\begin{array}{llll}\text { Journal of Leadership in } & \text { Education, }\end{array}$ https: //doi.org/10.1080/13603124.2016.1272719.

Kowiyah, K., Mulyawati, I., \& Umam, K. (2019). Conceptual Understanding and Mathematical Representation Analysis of Realistic Mathematics Education Based on Personality Types. Al-Jabar: Jurnal Pendidikan Matematika, 10(2), 201-210. https://doi.org/10.24042/ajpm.v10i2.4605.

Kowiyah, \& Mulyawati, I. (2018). An analysis of primary school students' representational ability in mathematics based on gender perspective. Journal of Physics: Conference Series, 948(1). https: //doi.org/10.1088/1742-6596/948/1/012016.

Kraft, M. A., \& Papay, J. P. (2014). Can professional environments in schools promote teacher development? Explaining heterogeneity in returns to teaching experience. Educational Evaluation and Policy Analysis, 36, 476-500. https://doi.org/10.3102/0162373713519496.

Leszczyński, P., Charuta, A., Łaziuk, B., Gałązkowski, R., Wejnarski, A., Roszak, M., \& Kołodziejczak, B. (2018). 
Multimedia and Interactivity in Distance Learning of Resuscitation Guidelines: A Randomised Controlled Trial. Interactive Learning Environments, 26(2), 151-162. https://doi.org/10.1080/10494820.2017.1337035.

Lin, S., Zhou, Y., \& Wijaya, T. T. (2020). Using hawgent dynamic mathematics software in teaching arithmetic operation. International Journal of Education and Learning, 2(1), 25-31. https://doi.org/10.31763/ijele.v2i1.97.

Márquez-García, M. J., Kirsch, W., \& Leite-Mendez, A. (2020). Learning and collaboration in pre-service teacher education: Narrative analysis in a service learning experience at Andalusian public schools. Teaching and Teacher Education, 96. https://doi.org/10.1016/j.tate.2020.103187.

Marshel, J., \& Ratnawulan. (2020). Analysis of Students Worksheet (LKPD) integrated science with the theme of the motion in life using integrated connected type 21st century learning. Journal of Physics: Conference Series, 1481(1). https://doi.org/10.1088/1742-6596/1481/1/012046.

Maulana, H. A. (2021). Psychological Impact of Online Learning during the COVID-19 Pandemic: A Case Study on Vocational Higher Education. Indonesian Journal of Learning Education and Counseling, 3(2), 130-139. https://doi.org/10.31960/ijolec.v3i2.833.

Mpungose, C. B. (2021). Lecturers' reflections on use of Zoom video conferencing technology for e-learning at a South African university in the context of coronavirus. African Identities. https://doi.org/10.1080/14725843.2021.1902268.

Mutlu, A. (2020). Evaluation of students' scientific process skills through reflective worksheets in the inquiry-based learning environments. Reflective Practice, 21(2). https://doi.org/10.1080/14623943.2020.1736999.

Nenotaek, B., Sujadi, I., \& Subanti, S. (2019). The Difficulties in Implementing Scientific Approach for Mathematics Learning. International Journal of Educational Research Review. https: //doi.org/10.24331/ijere.628448.

Novita, R., \& Putra, M. (2017). Peran Desain Learning Trajectory Nilai Tempat Bilangan Berbantukan Video Animasi Terhadap Pemahaman Konsep Nilai Tempat Siswa Kelas II SD. Jurnal Pendidikan Matematika, 11(7). https://doi.org/10.22342/jpm.11.1.3802.

Nugroho, P. B., Nusantara, T., As'ari, A. R., Sisworo, Hidayanto, E., \& Susiswo. (2018). Critical Thinking Disposition: Students Skeptic in Dealing with Ill-Logical Mathematics Problem. International Journal of Instruction, 11(3), 635-648. https://doi.org/10.12973/iji.2018.11343a.

Nurlaily, V. A., Soegiyanto, H., \& Usodo, B. (2019). Elementary school teacher's obstacles in the implementation of problem-based learning model in mathematics learning. Journal on Mathematics Education, 10(2), 229-238. https://doi.org/10.22342/jme.10.2.5386.229-238.

Öztürk, M., Akkan, Y., \& Kaplan, A. (2020). Reading comprehension, Mathematics self-efficacy perception, and Mathematics attitude as correlates of students' non-routine Mathematics problem-solving skills in Turkey. International Journal of Mathematical Education in Science and Technology, 51(7), 1042-1058. https://doi.org/10.1080/0020739X.2019.1648893.

Partovi, T., \& Razavi, M. R. (2019). The effect of game-based learning on academic achievement motivation of elementary school studentsNo Title. Learning and Motivation, 68. https://doi.org/10.1016/j.lmot.2019.101592.

Pentury, H., Festiyed, Hamdi, \& Yurnetti. (2019). Pembuatan Lembar Kerja Peserta Didik (LKPD) Berbasis Model Discovery Learning Pada Materi Gelombang Berbantuan Aplikasi Android Untuk Kelas XI SMA/MA. Pillar of Physics Education, 12(4), 617-624. https://doi.org/10.24036/7144171074.

Pratama, I. G. D. J., Dantes, N., \& Yudiana, K. (2020). Thematic Learning Plan With A Nature Of Science Learning Model In The Fourth Grade Of Elementary School. International Journal of Elementary Education, 4(4), 447-453.

Rahma, N. A., \& Pujiastuti, H. (2021). Efektivitas Pembelajaran Daring Matematika Pada Masa Pandemi Covid-19 Di Kota Cilegon [the Effectiveness of Mathematics Online Learning During the Covid-19 Pandemic in Cilegon City]. JOHME: Journal of Holistic Mathematics Education, 5(1), 1. https://doi.org/10.19166/johme.v5i1.3811.

Riyanto, W. D., \& Gunarhadi, G. (2017). The Effectiveness of Interactive Multimedia in Mathematic Learning: Utilizing Power Points for Students with Learning Disability. IJPTE: International Journal of Pedagogy and Teacher Education, 1(1), 55-63. https://doi.org/10.20961/ijpte.v1i1.8400.

Ro'fah et al. (2020). Is Online Learning Accessible During COVID-19 Pandemic ? Voices and Experiences of UIN Sunan Kalijaga Students with Disabilities. Nadwa: Jurnal Pendidikan Islam, 14(1), 1-38. https: //doi.org/10.21580/nw.2020.14.1.5672.

Rodríguez-Izquierdo, R. M. (2021). Does service learning affect the development of intercultural sensitivity? A study comparing students' progress in two different methodologies. International Journal of Intercultural Relations, 82. https://doi.org/10.1016/j.ijintrel.2021.03.005. 
Ronfeldt, M., Loeb, S., \& Wyckoff, J. (2013). How teacher turn- over harms student achievement. American Educational Research Journal, 50, 4-36. https://doi.org/10.3102/0002831212463813

Rosala, D., \& Budiman, A. (2020). Local Wisdom-based Dance Learning: Teaching Characters to Children through Movements. Mimbar Sekolah Dasar, 7(3), 304-326. https://doi.org/10.17509/mimbarsd.v7i3.28185.

Russo, J., Bobis, J., Downton, A., Livy, S., \& Sullivan, P. (2021). Primary teacher attitudes towards productive struggle in mathematics in remote learning versus classroom-based settings. Education Sciences, 11(2), 1-13. https://doi.org/10.3390/educsci11020035.

Russo, J., Bobis, J., Sullivan, P., Downton, A., Livy, S., McCormick, M., \& Hughes, S. (2020). Exploring the relationship between teacher enjoyment of mathematics, their attitudes towards student struggle and instructional time amongst early years primary teachers. Teaching and Teacher Education, 88(102983), 1-9. https://doi.org/10.1016/j.tate.2019.102983.

Samri, F., Rewo, J. M., \& Laksana, D. N. . (2020). Electronic Thematic Teaching Multimedia with Local Culture Based Materials and Its Effect on Conceptual Mastery of Primary School Students. European Journal of Education Studies, 7(2), 625-641. https://doi.org/10.46827/ejes.v7i12.3474.

Sari, I. P., \& Purnama, T. (2014). Tingkat Pengetahuan Tentang Pentingnya Mengkonsumsi Air Mineral Pada Siswa Kelas IV di SD Negeri Keputran A Yogyakarta. Jurnal Pendidikan Jasmani Indonesia, 10(2). https://doi.org/https://doi.org/10.21831/jpji.v10i2.5701.

Sari, N. R., Anggo, M., \& Kodirun, K. (2019). Desain Pembelajaran Bilangan Melalui Permainan Sut-Sut Menggunakan Pendekatan PMRI Di Kelas III Sekolah Dasar. Jurnal Pendidikan Matematika, 9(1). https://doi.org/10.36709/jpm.v9i1.5758

Shafie, Shahdan, \& Liew. (2010). Mastery Learning Assessment Model (MLAM) in teaching and learning $\begin{array}{llll}\text { mathematics. Procedia-Social and } & \text { Behavioral }\end{array}$ https://doi.org/10.1016/j.sbspro.2010.12.040.

Solehana, L., Asrori, A., \& Usman, A. (2019). The Development of E-Learning Teaching Material Based on Edmodo on Basic Competencies of National Integration at Class X of Senior High School. Journal Of Education, Teaching And Learning, 4(2). https://doi.org/10.26737/jetl.v4i2.1914.

Sopia, H. F., \& Wutsqa, D. U. (2015). Keefektifan Pendekatan Realistik Ditinjau dari Prestasi Belajar, Kemampuan Pemecahan Masalah, dan Kepercayaan Diri Matematika. PYTHAGORAS: Jurnal Pendidikan Matematika, 10(2), 146-154. https://doi.org/10.21831/pg.v10i2.9139.

Sugiyanto, S., Wena, M., \& Isnandar, I. (2019). Developing Learning Materials Based On Training Within Industry (Twi) To Improve The Building Construction Student's Learning Outcomes. Jurnal Ilmu Pendidikan, 24(2). https: //doi.org/10.17977/um048v24i2p80-85.

Sulastri, S., \& Kusmanto, B. (2016). Upaya Meningkatkan Motivasi Dan Prestasi Belajar Matematika Melalui Model Rme (Realistic Mathematics Education) Siswa Kelas Ix a Smp Negeri 04 Bumiayu Semerter 1 Tahun Pelajaran 2013/2014. UNION: Jurnal Ilmiah Pendidikan Matematika, 4(3), 435-444. https://doi.org/10.30738/.v4i3.443.

Sulastri, S., Marwan, M., \& Duskri, M. (2017). Kemampuan Representasi Matematis Siswa SMP Melalui Pendekatan Pendidikan Matematika Realistik. Beta: Jurnal Tadris Matematika, 10(1). https://doi.org/10.20414/betajtm.v10i1.101

Suryawati, E., Suzanti, F., Zulfarina, Putriana, A. R., \& Febrianti, L. (2020). The implementation of local environmental problem-based learning student worksheets to strengthen environmental literacy. Jurnal Pendidikan IPA Indonesia, 9(2), 169-178. https://doi.org/10.15294/jpii.v9i2.22892.

Syafrijal, \& Desyandri. (2019). Deveopment Of Integrated Thematic Teaching Materials With Project Based Learning Models In Class IV of Primary School. International Journal of Educational Dynamics/IJEDS, 1(2), 87-92. https://doi.org/10.24036/ijeds.v1i2.110.

Tanudjaya, C. P., \& Doorman, M. (2020). Examining higher order thinking in Indonesian lower secondary mathematics classrooms. Journal on Mathematics Education, 11(2), 277-300. https: //doi.org/10.22342/jme.11.2.11000.277-300.

Taylor, A. T. S., Olofson, E. L., \& Novak, W. R. P. (2017). Enhancing student retention of prerequisite knowledge through pre-class activities and in-class reinforcement. Biochemistry and Molecular Biology Education, 45(2), 97-104. https://doi.org/10.1002/bmb.20992.

Toropova, A., Myrberg, E., \& Johansson, S. (2021). Teacher job satisfaction: the importance of school working conditions and teacher characteristics. Educational Review, 73(1), 71-97. https: //doi.org/10.1080/00131911.2019.1705247.

Wahyuni, D. (2019). Pengembangan Multimedia Pembelajaran Matematika Dengan Pendekatan Matematika Realistik. AKSIOMA: Jurnal Program Studi Pendidikan Matematika, 8(1), 32-40. https: //doi.org/10.24127/ajpm.v8i1.1711.

Wardoyo, C., \& Article, H. (2016). Developing Learning Media Based on E-Learning on Accounting Subject 
for Senior High School Students. Dinamika Pendidikan Unnes, 11(2), 84-93. https://doi.org/10.15294/dp.v11i2.8932.

Yulianty, N. (2019). Kemampuan Pemahaman Konsep Matematika Siswa Dengan Pendekatan Pembelajaran Matematika Realistik. Jurnal Pendidikan Matematika Raflesia, 4(1), 60-65. https://doi.org/10.33449/jpmr.v4i1.7530.

Yuniarti, A., \& Radia, E. H. (2020). Development of Comic Mathematics Teaching Materials on Flat- Building Material to Increase Reading Interest in Class IV Elementary School Students. Journal of Education Technology, 4, 415-423. https://doi.org/10.23887/jet.v4i4.30034.

Yustina, \& Kapsin. (2017). The implementation of constructivism-based student worksheets within the theme 'the prevention of land and forest fire' in science education for seventh graders in Riau. Jurnal Pendidikan IPA Indonesia, 6(2), 298-305. https://doi.org/10.15294/jpii.v6i2.10573.

Zulimah, Abdurrahman, \& Jalmo, T. (2018). The Effectiveness of Students Worksheet of Virtual Laboratory Practice on Dynamic Electricity to Improve Science Process Skill. International Journal of Advanced Engineering, Management and Science (IJAEMS), 4, 319-328. https://doi.org/10.22161/ijaems.4.4.14. 